\title{
Anthropology museum fights art gallery plan
}

Paris. The fate of the world's largest anthropology museum, le Musée de l'Homme (Museum of Mankind) in Paris, is hanging on the outcome of a bitter dispute between museum scientists, who want to renovate the existing museum, and art specialists who want to turn it into a museum of primitive, or 'early', art.

A facelift for the museum has been on the cards since 1989, when François Mitterrand, the Socialist president at the time, launched a FFr1-billion (\$200million) programme to renovate the four museums which belong to the education ministry.

Staff at the museum want to repeat the success of the FFr500-million renovation of the Natural History Museum's Grande Galerie d'Evolution, which reopened in 1993 after being closed to the public for almost thirty years. Its exhibitions, complete with light and sound effects, now rank among Paris's top attractions.

But plans to renovate the anthropology museum have been complicated by the government's decision to add collections from the Museum of African and Oceanic Arts. Both collections contain valuable items of primitive art, and in January, Jacques Chirac, the French president, set up a commission to review how the joint collections could be best exhibited. (Chirac, a connoisseur of primitive art, is said to have been influenced in his decision by his friend Jacques Kerchache, an art collector and former dealer in African art.)

The commission is split between two competing visions of the museum. Henry de Lumley - who is director of the Museum of Mankind's parent body, the Natural History Museum, and a member of the commission - has proposed a FFr400-million renovation that would expand the museum's research capacity and provide a spectacular public showcase for some of its 735,000 objects, with exhibitions showing the sweep of mankind's social, cultural and biological evolution. The remainder of the collections would be housed in a purpose-built 6,000 square-metre facility beneath the museum. (Many objects are at present stacked haphazardly in rooms and corridors at the museum.)

But several members of the commission are said to favour turning the museum into a

\section{IMAGE UNAVAILABLE FOR COPYRIGHT REASONS}

proposal to create a "Grand Musée d'Histoire Naturelle de l'Homme".

Those supporting De Lumley's proposal include two Nobel prizewinners, François Jacob and Jean Dausset, as well as Ellen Futter, president of the American Museum of Natural History in New York, and Theya Molleson, a member of the department of palaeontology at the Natural History Museum in London.

Jacob says the proposal to turn the $\approx$ museum into a centre of primitive art would be a "regrettable error". Torben Lundbaeck, director of the Danish National Museum of Ethnography, says that the museum's distinctive characteristic has been to nurture links between biological anthropology, archaeology and ethnology, as well as between research and teaching. "A change in these I relationships would seriously \& damage the identity of the museum," he says.

Science or art? De Lumley (right) wants to expand the research capacity of the Paris Musée de l'Homme (above).

\section{IMAGE UNAVAILABLE FOR COPYRIGHT}

The commission recently submitted its report to Chirac, who later this year will inform the government of his pre-

centre of primitive art; research would be abandoned, and large parts of its collections might be sold. Members of the commission said to support the creation of a museum of primitive art include Kerchache, Françoise Cachin, the head of the French museums authority, and Jean-Hubert Martin, the head of the Museum of African and Oceanic Arts.

De Lumley describes the choice between his proposal and the latter as "between renovating or dismantling" the museum. To defend his proposal, De Lumley has broken the requirement that members of the commission refrain from commenting publicly on its deliberations, and has mounted an international campaign in support of his ferred option. According to Christine Albanel, his adviser for education and culture, the probable outcome will be a compromise, resulting in the creation of a new museum of "civilization" that would cater both for science, in particular ethnology, and for art. "I think the president's desire is that everybody will find an advantage," she says.

But the new museum would be separated from the Natural History Museum, and belong not only to the ministry of education but also to the ministry of culture. The Natural History Museum describes this arrangement as "unacceptable", and claims that the proposal itself is nothing more than a fudge aimed at disguising the "destruction" of the Museum of Mankind.

Declan Butler

\section{Labor resists reductions in Australian research incentives}

Sydney. Australia's opposition Labor Party is to challenge several of the recent budget proposals for reducing expenditure on research and higher education by the new Coalition government in a move that, unusually, has placed science and university policies centre-stage in Australian politics.

In particular, Kim Beazley, the leader of the opposition, is to oppose reductions in tax incentives for industrial research and development (R\&D) worth A\$1.9 billion (US\$1.5 billion) over fours years, and a proposed doubling of deferred course fees, known as higher education credits (HECs), for students choosing science-based courses, worth $\mathbf{A} \$ \mathbf{1 . 1 3}$ billion (see Nature 382, $659 \&$ 383, 8; 1996).
Both proposals are vulnerable, as they require amendments to tax laws which must pass the upper house, the Senate, where the Liberal and National parties are a minority. But the opposition party does not intend to challenge the proposed pruning of operating grants for universities and research agencies. These are integral parts of the budget bill, defeat of which would lead to a new election, which the weakened opposition is not pursuing.

In a television interview, Peter McGauran, the Science and Technology Minister, described the opposition's move as "grossly irresponsible". He claimed that the reduced concession of 125 per cent is "a very generous tax incentive" and "the 150 per cent was very inefficient". But Simon Crean, the opposition spokesman on industry, predicted that $R \& D$ "will go overseas as a result of the cuts".

The exchanges on the budget have overshadowed an announcement by McGauran of a year-long inquiry to develop a strategy for marine research to support Australia's recently increased $200-\mathrm{km}$ economic zone, among the largest in the world. Meanwhile, the vice-chancellors of the Universities of Sydney and Melbourne have called on the Senate to approve the HECs bill to protect higher education against further financial pressures. Peter Pockley - See the Commentary, New era of fiscal restraint in Australia', page 117 